\title{
Relationship Between The Characteristics Of The Wound And The Event of Patient Infection
}

\author{
Darmila ${ }^{1}$, Nadia Alfira ${ }^{2}$, Muriyati $3^{*}$, Andi Baso Tombong ${ }^{4}$ \\ Nursing Study Program, Stikes Panrita Husada Bulukumba, Indonesia ${ }^{1}$ \\ Surgical Medical Nursing Department, Stikes Panrita Husada Bulukumba, Indonesia 2,3 \\ RSUD H.A.Sulthan Dg.Radja Bulukumba, Indonesia ${ }^{4}$
}

*Corresponding Autor : muriyatirisman@gmail.com

\begin{abstract}
The results of observations at RSUD H. Andi Sultan Daeng Radja carried out observations on all types of wounds that entered the emergency room with each wound characteristic observed, namely the location of the wound, the shape of the wound, the size of the wound, the depth of the wound, and the wound edge. Research Objectives To determine the relationship between wound characteristics and infection incidence in RSUD H. Andi Sulthan Daeng Radja, Bulukumba Regency. The research design is quantitative research. This study used a cross-sectional design. The sample size is 14 people. Results Based on the Fisher exact test, the value of $p=0.005(<\alpha=$ 0.05 ) was obtained, which means that there is a significant relationship between the location of the wound and the incidence of infection. Kolmogorov Smirnov test results obtained p-value $=$ $0.016(<\alpha=0.05)$, which means that there is a significant relationship between the shape of the wound and the incidence of infection. Kolmogorov Smirnov test results obtained $p$-value $=0.010$ $(<\alpha=0.05)$, which means that there is a significant relationship between wound size and the incidence of infection. Kolmogorov Smirnov test results obtained p-value $=0.002(<\alpha=0.05)$, which means that there is a significant relationship between wound depth and the incidence of infection. The Kolmogorov Smirnov test results obtained p-value $=0.267(>\alpha=0.05)$, which means that there is no significant relationship between the wound edges and the incidence of infection. Conclusion and suggestion that there is a significant relationship between the location, shape, size, and depth of the wound and the incidence of infection. It is hoped that there will be further research with a larger number of samples with in-depth studies.
\end{abstract}

Keywords: wound characteristics, the incidence of infection.

\section{INTRODUCTION}

The wound is a very incidental and occasional disturbance. However, wounds require prompt and appropriate treatment, so that wound healing is following the healing time and do not cause complications such as hematomas, infections, keloids, or hypertrophic tissue (Hardiyanti, 2015). The impact or consequences of wounds due to not doing proper wound care are hematomas, soft tissue necrosis, keloids, scars, and infection (Delima, 2014). Infection is the occurrence of severe local inflammation and usually with the formation of pus (pus) (Ekawati and Herawati, 2018). 
According to a survey from the World Health Organization (WHO), 5\% -34\% of total nosocomial infections come from wound infections due to surgery (Sulviana, 2017). The incidence of tearing injuries in America is approximately 2.5 million people who require medical assistance every year and around 12,000 of them have died from severe torn injuries (Tasijawa, 2018). In Indonesia, the prevalence of wound infection is around 2.318.3\% (Muttaqien et al., 2016).

One thing that can happen to a wound is an infection. Infection is a disease caused by pathogenic microbes which are very dynamic. Infection is part of the effect of the invasion of pathogenic microorganisms into the body and the tissue reactions that occur in the host to their toxin organisms (Rahmawanto, 2015).

Hospital Infection Prevention and Control (PPIRS) Cipto Mangunkusumo Hospital (RSCM) reported a 4.3\% incidence of wound infection due to surgery in the surgical ward (Haryanti et al., 2016). The Surveillance Sub-Directorate General of Communicable Diseases Eradication and Environmental Health for Human Settlements (Ditjen PPM \& PLP) in 10 public hospitals obtained quite high results. The survey results show that the incidence rate of nosocomial infections is $6 \%$ to $16 \%$ with a mean of $9.8 \%$. In the capital city of Indonesia itself, Jakarta, the prevalence of nosocomial infection is $\pm 41.1 \%$, in Surabaya $\pm 73.3 \%$, and Yogyakarta $\pm 5.9 \%$ (Wulandari et al., 2016). Data for nosocomial infections in South Sulawesi itself mentions Dr. Wahidin Sudirohusodo by 4.4\%. In Makassar Haji Hospital, it was found that the incidence of nosocomial infections was $3.44 \%$ (Sommeng, 2019). Based on a case report that started with a minor infection at the H. Andi Sultan Daeng Radja Bulukumba Regional Hospital in 2017, there were 496 cases while in 2018 there were 515 cases.

Research conducted by Roodsari in 2015 provided the results of research, namely that there were 6 patients (5\%) with wound infections reported with simple hand lacerations with the degree of injury, while age, sex, diabetes, antibiotics, and closure techniques did not affect the risk of infection. Meanwhile, Quin's study (2015) provides research results, namely a history of diabetes, wound contamination, wounds more than $5 \mathrm{~cm}$ long, and located in the lower extremities are very high-risk factors for infection. The results of observations at RSUD H. Andi Sultan Daeng Radja carried out observations on all types of wounds that entered the emergency room with each wound characteristic observed, namely the location of the wound, the shape of the wound, the size of the wound, the depth of the wound, and the wound edge. Mean observed in the ER with 
vulcanic patients where they were located in the upper and lower extremities. The facts found, the location on the lower extremities with an irregular open wound shape, irregular size, visible depth of about $4-5 \mathrm{~cm}$, and the wound edges that needed treatmentexperienced slow wound healing because when the wound was first found it looked dirty so that the time of contamination and causes infection more quickly then the lower extremities are also used more frequently so that the healing process takes a long time. On the 4th day after the injury, when it was time to change the bandage, 3 of the 4 patients showed that the wound was still very wet, had pus, and smelled and around the red wound. The situation is in the state of infection on day 4.

This situation illustrates that the incidence of infection can depend on the characteristics of the wound. Lacerated wounds that are sometimes torn irregularly describe the degree of injuries such as the location of the wound, open wounds, causes of injuries, disease/effects caused by injuries such as open fractures, and wound contamination which contribute to a very wide range of infections. With the determination of the degree of the wound, in the future, the management of the wound can be done properly based on the characteristics of the wound. Therefore, the researchers were interested in conducting research at the H. Andi Sultan Daeng Radja Regional Hospital regarding the relationship between wound characteristics and the incidence of infection in the wound.

\section{MATERIAL AND METHODS}

The research was conducted at RSUD H. Andi Sultan Daeng Radja Bulukumba. The research design was qualitative with a cross-sectional design approach. The independent variable is wound characteristics and the dependent variable is the incidence of infection. The population in this study was an affordable population, namely patients who had injuries at the H. Andi Sultan Daeng Radja Bulukumba Regional Hospital. The sample size is 14 people.

The observation sheet for wound characteristics used in this study is the observation sheet Bates Jensen Wound Assessment Tool has been used by Ghifari (2018) in his research which was later modified by researchers, namely wound characteristics which include wound location, wound shape, wound size, wound depth, edge. wound. The observation sheet for the incidence of wound infection was modified from the literature review, namely the presence of clinical signs of infected wounds such as wounds 
expanding (not repairing), pain, high fever, redness of the wound edges, more pus, and odor.

Data analysis is shown to answer the research objectives and test the research hypothesis (Nursalam, 2009). For this, the statistical tests to be used are the Pearson Cs test and the Kolmogorov alternative test using the SPSS 22 statistical test computer program (Dahlan, 2014).

\section{RESULTS}

Table 1. Frequency Distribution of Wound Characteristics

\begin{tabular}{|c|c|c|}
\hline Characteristics of Wounds & Frequency (f) & Percentage (\%) \\
\hline \multicolumn{3}{|l|}{ Location of the Wound } \\
\hline On & 7 & 50,0 \\
\hline Under & 7 & 50,0 \\
\hline \multicolumn{3}{|l|}{ Wound Shape } \\
\hline Regular & 4 & 28,6 \\
\hline Circular / ovale & 6 & 42,9 \\
\hline Irregular & 4 & 28,6 \\
\hline \multicolumn{3}{|l|}{ Wound Size } \\
\hline$<4 \mathrm{~cm}$ & 3 & 21,4 \\
\hline $4-15 \mathrm{~cm}$ & 4 & 28,6 \\
\hline $16-35 \mathrm{~cm}$ & 4 & 28,6 \\
\hline $36-80 \mathrm{~cm}$ & 2 & 14,3 \\
\hline$\geq 80 \mathrm{~cm}$ & 1 & 7,18 \\
\hline \multicolumn{3}{|l|}{ Wound Depth } \\
\hline Stage 2 & 6 & 42,9 \\
\hline Stage 3 & 5 & 35,7 \\
\hline Stage 4 & 2 & 14,3 \\
\hline Necrosis Wound & 1 & 7,1 \\
\hline \multicolumn{3}{|l|}{ Edge of the Wound } \\
\hline Samar & 1 & 7,1 \\
\hline Visible Edges & 4 & 28,6 \\
\hline Clearly Thin & 4 & 28,6 \\
\hline Clear Thick & 2 & 14,3 \\
\hline Clear Grate & 3 & 21,4 \\
\hline Amount & 14 & 100 \\
\hline
\end{tabular}

Based on table 2 it can be seen that of the 14 respondents at H. Andi Sultan Daeng

Radja Hospital, there were a number of respondents based on the characteristics of the wound, namely the location of the wound, namely 7 people (50.0\%) and below 7 people (50.0\%) whereas based on the shape of the wound, namely regular as many as 4 people (28.6\%), oval as many as 6 people (42.9\%) and irregular as many as 4 people $(28.6 \%)$ then based on the size of the wound which is at most $4-15 \mathrm{~cm}$ and $16-35 \mathrm{~cm}$ each as many as 4 people (28.6\%). Based on the depth of the wound, there were at most stage 2 as 
many as 6 people (42.9\%). Meanwhile, based on the edges of the wound, the most were visible and clearly thin borders, each of which was 4 people (28.6\%).

Table 3. Frequency Distribution of Infection

\begin{tabular}{lcc}
\hline Incidence of Infection & Frequency (f) & Percentage (\%) \\
\hline There is & 8 & 57,1 \\
There is no & 6 & 42,9 \\
\hline Amount & $\mathbf{1 4}$ & $\mathbf{1 0 0}$ \\
\hline
\end{tabular}

Based on table 3, it can be seen that of the 14 respondents at H. Andi Sultan Daeng Radja Hospital, there were a number of respondents based on the incidence of infection, namely 8 people (57.1\%) and no infection as many as 6 people (42.9\%) ).

Table 4. Relationship Of Wound Location, Wound Shape, Size Of Wound, Depth Of Wound, Edge of Wound And Incidence Of Infection

\begin{tabular}{|c|c|c|c|c|c|c|c|}
\hline \multirow{3}{*}{$\begin{array}{l}\text { Location of the } \\
\text { Wound }\end{array}$} & \multicolumn{4}{|c|}{ Incidence of Infection } & \multicolumn{2}{|c|}{ Amount } & \multirow[t]{2}{*}{ Pvalue } \\
\hline & \multicolumn{2}{|c|}{ There is } & \multicolumn{2}{|c|}{ None } & & & \\
\hline & f & $\%$ & f & $\%$ & $\mathbf{n}$ & $\%$ & \\
\hline On & 7 & 100 & 0 & 0 & 7 & 100 & \\
\hline Under & 1 & 14,3 & 6 & 85,7 & 7 & 100 & 0,005 \\
\hline Amount & 8 & 57,1 & 6 & 42,9 & 14 & 100 & \\
\hline \multirow{3}{*}{ Wound Shape } & \multicolumn{4}{|c|}{ Incidence of Infection } & \multirow{2}{*}{\multicolumn{2}{|c|}{ Amount }} & \multirow{7}{*}{$P$ Value } \\
\hline & \multicolumn{2}{|c|}{ There is } & \multicolumn{2}{|c|}{ None } & & & \\
\hline & f & $\%$ & f & $\%$ & $\mathbf{n}$ & $\%$ & \\
\hline Regular & 4 & 100 & 0 & 0 & 4 & 100 & \\
\hline Circular / oval & 0 & 0 & 6 & 100 & 6 & 100 & \\
\hline Irregular & 4 & 100 & 0 & 0 & 4 & 100 & \\
\hline Amount & 8 & 57,1 & 6 & 42,9 & 14 & 100 & \\
\hline \multirow[t]{3}{*}{ Wound Size } & \multicolumn{4}{|c|}{ Incidence of Infection } & \multicolumn{2}{|c|}{ Amount } & $P$ Value \\
\hline & \multicolumn{2}{|c|}{ There is } & \multicolumn{2}{|c|}{ None } & & & \\
\hline & f & $\%$ & f & $\%$ & $\mathrm{n}$ & $\%$ & \\
\hline$<4 \mathrm{~cm}$ & 1 & 33,3 & 2 & 66,7 & 3 & 100 & \\
\hline $4-15 \mathrm{~cm}$ & 0 & 0 & 4 & 100 & 4 & 100 & \\
\hline $16-35 \mathrm{~cm}$ & 4 & 100 & 0 & 0 & 4 & 100 & \\
\hline $36-80 \mathrm{~cm}$ & 2 & 100 & 0 & 0 & 2 & 100 & 0,010 \\
\hline$>80 \mathrm{~cm}$ & 1 & 100 & 0 & 0 & 1 & 100 & \\
\hline Amount & 8 & 57,1 & 6 & 42,9 & 14 & 100 & \\
\hline \multirow[t]{3}{*}{ Wound Depth } & \multicolumn{4}{|c|}{ Incidence of Infection } & \multicolumn{2}{|c|}{ Amount } & $P$ Value \\
\hline & \multicolumn{2}{|c|}{ There is } & \multicolumn{2}{|c|}{ None } & & & \\
\hline & f & $\%$ & f & $\%$ & $\mathbf{n}$ & $\%$ & \\
\hline Stage 2 & 0 & 0 & 6 & 100 & 6 & 100 & \multirow{4}{*}{0,002} \\
\hline Stage 3 & 5 & 100 & 0 & 0 & 5 & 100 & \\
\hline Stage 4 & 2 & 100 & 0 & 0 & 2 & 100 & \\
\hline Necrosis Wound & 1 & 100 & 0 & 0 & 1 & 100 & \\
\hline Amount & 8 & 57,1 & 6 & 42,9 & 14 & 100 & \\
\hline \multirow{3}{*}{$\begin{array}{l}\text { Edge of the } \\
\text { Wound }\end{array}$} & \multicolumn{4}{|c|}{ Incidence of Infection } & \multirow{2}{*}{\multicolumn{2}{|c|}{ Amount }} & \multirow{3}{*}{$P$ Value } \\
\hline & & & & & & & \\
\hline & f & $\%$ & f & $\%$ & $\mathrm{n}$ & $\%$ & \\
\hline Samar & 1 & 100 & 0 & 0 & 1 & 100 & \\
\hline Visible Edges & 0 & 0 & 4 & 100 & 4 & 100 & \\
\hline Clearly Thin & 4 & 100 & 0 & 0 & 4 & 100 & 0,267 \\
\hline Clear Thick & 2 & 100 & 0 & 0 & 2 & 100 & \\
\hline
\end{tabular}




\begin{tabular}{ccccccc} 
Clear Grate & 1 & 33,7 & 2 & 66,7 & 3 & \\
\hline Amount & 8 & 57,1 & 6 & $\mathbf{4 2 , 9}$ & $\mathbf{1 4}$ & $\mathbf{1 0 0}$ \\
\hline
\end{tabular}

Based on table 4, it can be seen that of the 14 respondents at H. Andi Sultan Daeng Radja Hospital, there were 7 respondents with the upper wound location having infection 7 people (100\%) while the lower wound location was 1 person (14.3\%). ) experienced infection and as many as 6 people did not experience infection. So as a percentage it can be concluded that there is a relationship between the location of the wound and the incidence of infection in the H. Andi Sultan Daeng Radja Hospital, Bulukumba Regency. The results of the fisher exact test obtained p value $=0.005(<\alpha=0.05)$, which means that there is a significant relationship between the location of the wound and the incidence of infection. it can be seen that of the 14 respondents at H. Andi Sultan Daeng Radja Hospital, there were 4 people with regular wound forms and 4 people experiencing infection (100\%) and 6 people with circular / oval wounds (100\%). \%).

Did not experience infection while the wound was irregular as many as 4 people $(100 \%)$ and had an infection. Kolmogorov Smirnov test results obtained $\mathrm{p}$ value $=0.016$ $(<\alpha=0.05)$, which means that there is a significant relationship between the shape of the wound and the incidence of infection. it can be seen that of the 14 respondents at $H$. Andi Sultan Daeng Radja Hospital, there were 3 respondents with a wound size $<4 \mathrm{~cm}$ and 1 person (33.3\%) who did not experience infection. (66.7\%). The wound size was 4$5 \mathrm{~cm}$ as many as 4 and did not experience infection as well as 4 people (100\%). The wound size was $16-35 \mathrm{~cm}$, as many as 4 people and had infection as many as 4 people (100\%). The wound size was $36-80 \mathrm{~cm}$ for 2 people and 2 people had infection $(100 \%)$, while the size $>80 \mathrm{~cm}$ was 1 person (100\%) and had an infection. Kolmogorov Spirnov test results obtained $\mathrm{p}$ value $=0.010(<\alpha=0.05)$, which means that there is a significant relationship between wound size and the incidence of infection.

Based on table 5.7 above, it can be seen that of the 14 respondents at H. Andi Sultan Daeng Radja Hospital, there were 6 respondents with stage 2 and 6 people did not experience infection (100\%). Stage 3 as many as 5 people and experienced infection as many as 5 people (100\%). Stage 4 as many as 2 people and experienced infection as many as 2 people (100\%). As many as 1 person had necrosis wound and 1 person had infection (100\%). Kolmogorov Spirnov test results obtained p value $=0.002(<\alpha=0.05)$, which means that there is a significant relationship between wound depth and the incidence of infection. it can be seen that of the 14 respondents at H. Andi Sultan Daeng Radja Hospital, 
there were 1 person with faint wound margins and 1 person (100\%). The border was seen in 4 people and 4 people did not experience infection (100\%). Clearly thin as many as 4 people and had infections as many as 4 people (100\%). Obviously thick as many as 2 people and experienced infection by 2 people (100\%). Meanwhile, 3 people had clear scar edges and 1 (33.7\%) had infection and 2 (66.7\%) had no infection. The Kolmogorov Spirnov test results obtained p value $=0.267(>\alpha=0.05)$, which means that there is no significant relationship between the wound edges and the incidence of infection.

\section{DISCUSSION}

The wound location is the place where the injury to the patient's anatomy occurs. The location of the wound needs to be known to predict wound healing. The location of the wound has been shown to influence healing. However, which specific location is beneficial or detrimental to healing remains to be determined (Ghifari, 2018). Based on research results that are not in line with Omoke's (2016) research with the title of the research, namely Analysis of Risk Factors for Gunshot Wound Infection in a Nigerian Civilian Trauma Setting states that wound infection is based on location, namely the highest level (40.6\%) in the lower extremities and the least (9.1\%) on head and neck wounds.

So the researchers assumed that the wound location anywhere could be infected because it depends on the type of treatment and the level of contamination, but the highest risk is the wound being contaminated for longer. In this study, the location is a factor that is prone to infection, such as in the location of the extremities where it is easy for bacteria to adhere to the area because it is quickly displayed with outside conditions or when an injury occurs. Besides, the incidence of infection in this study was balanced between the locations of the upper and lower wounds. Where the upper locations include the head, neck, upper extremities, and trunk. It is known that the tissue at this location has a fast healing rate, in addition to a good blood flow rate and tissue that is easy to form so that the infection phase is very easy to resolve properly.

In contrast to the location of wounds in the lower part or lower extremities, the lower tissue is quite hard and the healing rate is slow due to gravity and the location where bacteria are easily exposed. Besides, vasoconstriction occurs more easily on the upper part than the lower wound. For wounds that are healing, they will often change shape and may have a more regular, circular or oval shape. The shape of the wound is thought to be more helpful in determining the overall size of the wound. The shape of the wound is 
determined by evaluating the perimeter of the wound. The wound shape is lined with wound contraction. Wound contractions can be seen when the open wound surface area decreases and when the wound shape changes (Roodsari, 2015). This is not in line with research conducted by Roodsari (2015) entitled The risk of wound infection after simple hand laceration. The results of the study were based on the shape of the wound, 4 people (30\%) were infected and 83 (70\%) did not experience infection.

Researchers assume that the incidence of infection can still be closely related to the shape of the wound because the shape of the wound can determine improvements in future wound management actions. The regular wound shape makes it easier for medical personnel to perform the action properly and the possibility of the wound can be resolved properly as well as the patient's blood vessels. The shape of the wound on the first to the 7 th day there was a change because of the healing, but most of it was not significant so that it became a trigger for infection. The irregular shape of the wound results in a lot of tissue loss and irregularity in the initial treatment of infection. The size of the wound can be interpreted as the area of the patient's wound surface. The surface area can be seen by multiplying the length by the width. The most commonly used method of determining size is to measure (in $\mathrm{cm}$ ) the longest and perpendicular aspect of the visible wound surface. This can be difficult to determine in measuring the size of some wounds because the wound edges may be difficult to identify or the edges may be irregular (Ghifari, 2018).

Based on the results of the above research, it is in line with research conducted by Quinn (2014) with the research title Traumatic lacerations: what are the risks for infection and has the 'golden period of laceration care disappeared. The results of the study were based on the size of the wound $>5 \mathrm{~cm}, 13$ people experienced infection and 182 people were not infected while the wound size $<5 \mathrm{~cm}$ had an infection as many as 56 people and those who did not experience infection were 2396 and a p-value of 0.03 means there is a size relationship. wound with the incidence of infection.

Researchers assume that the size of the wound can greatly determine the incidence rate of infection, especially in wounds that have a higher length. This can be seen in this study that wound sizes above $35 \mathrm{~cm}$ are very prone to infection. The size of the wound on the first day was bigger and smaller on the 7th day of observation, this was because there was healing but not significant so that infection occurred. The size of the wound is wider, the vasoconstriction occurs in the tissue so that hemostasis is also slowly achieved. Is a measure of the wound bed to the wound surface. You can measure the depth of the 
wound using a cotton / cotton tip applicator. Insert the applicator in the deepest part of the wound and mark the applicator with a pen, and measure the distance from the marked tip, using a metric measurement guide (Ghifari, 2018).

Based on Yusuf's research (2019) with the research title Description of the characteristics of wounds and their treatment in the wound polyclinic room at $\mathrm{dr}$. Wahidin Sudirohusodo Makassar. The results of the study were 23 people (53.49\%) with the depth of the wound at the initial visit with a stage 4 depth. Researchers assume that the depth of the wrong factors can trigger the incidence of infection, this can be seen from the wound healing period, where if the wound heals during the inflammatory period, it is unlikely that you will be exposed to primary infection but this also cannot be ruled out that the depth of the wound describes the duration of healing so that wound care was preferred. The depth of the sutured wound did not show the real change, but it could be seen through the pus that was removed so that in this study there was pus that was still mixed with blood from the respondents who had a deeper depth than the others.

The wound edge is the area where normal tissue attaches to the wound bed. The wound edges show some of the most important characteristics of the wound. When assessing the edges of the wound, look at how the wound looks (Ghifari, 2018). Based on Yusuf's (2019) study, it was found that the edges of the wound were 27 people $(62.79 \%)$, the margins of the wound were visible, and they were fused with the wound. Meanwhile, Ghifari's research (2018) obtained data that respondents who had clear wound edge characteristics and did not integrate with the wound bed at the initial visit had a greater percentage, namely 33.8\% (49 people) when compared to other wound edge characteristics and decreased at the end. visits with a percentage of 18.6\% (27 people). The number of respondents who had wounds with faint and unclear wound edge characteristics had an increase when compared to other wound edge characteristics with an increase of $39.3 \%$ (57 people).

Researchers assumed that the wound margins in acute wounds could not clearly describe the effect of the incidence of infection, because when the wound was torn or the impact that determined the location, shape, depth, and size of the wound. In this study, the edges of the wound were blurred, clearly thick, clearly thin or the scar was infected, this could have happened in other circumstances. However, not all wounds can experience that, again that the wound edges like the type above can be affected by the condition of the wound that has been open for a long time or is contaminated. So it can 
be concluded that the wound edge is not a trigger for infection in acute wounds but is of particular concern in chronic wounds. Chronic wound margins determine the rate of wound healing.

\section{CONCLUSION}

There is a very significant relationship between wound characteristics and the incidence of wound infection, namely wound location, wound shape, wound size and wound depth. It is hoped that there will be further studies with a larger number of samples with in-depth assessment and controlling for factors such as age, patient nutritional status and strict control of wound care so that it is hoped that the data can be normally distributed and the results obtained are more accurate.

\section{REFERENCES}

Aisyah, S., Afandi, D. \& Burhanuddin, L. 2014. Penentuan Derajat Luka Berdasarkan Metode Evaluation of Impairment Pada Rekam Medis Pasien Rumah Sakit Bhayangkara Provinsi Riau Periode Januari-desember 2012. Riau University.

Alsen, M. A. M. \& Sihombing, R. 2015. Infeksi Luka Operasi. Majalah Kedokteran Sriwijaya, $46,229-235$.

Arisanty, P. Irma. 2013. Konsep Dasar Manajemen Perawatan Luka. Jakarta: EGC.

Ekawati, E. R. \& Herawati, D. 2018. Identifikasi Kuman pada Pus dari Luka Infeksi Kulit. Jurnal SainHealth, 2, 31-35.

Dahlan, Sopiyudin, 2014. Statistik Untuk Kedokteran dan Kesehatan. Jakarta: Epidemiologi Indonesia

Delima, M. 2015. Hubungan Perawatan Luka Dengan Proses Penyembuhan Luka Pada Klien Luka Robek (Vulnus Laceratum) Di Ruangan Bedah Rsi Ibnu Sina Bukittinggi Tahun 2013. 'AFIYAH, 1.

Fatriah, S. H., Sampurna, B. \& Firmansyah, A. 2017. Medicolegal Analysis on the Degree of Injury According to the National Criminal Code. JOURNAL OF THE INDONESIAN MEDICAL ASSOCIATION Majalah Kedokteran Indonesia, 67.

Gurtner, G. C. \& Wong, V. 2007. Wound healing: normal and abnormal. Grabb and Smith's plastic surgery, 6, 15-22.

Gifari, M. 2018. Gambaran Karakteristik Luka Dan Perawatannya Di Klinik Perawatan Luka Griya Afiat Makassar. Makassar: Fakultas Keperawatan Unhas.

Hardiyanti, S. \& Dirdjo, M. M. 2015. Analisis Praktik Klinik Keperawatan pada Pasien Vulnus Laceratum dengan Perawatan Luka Modern di Ruang Instalasi Gawat Darurat RSUD Abdul Wahab Sjahranie Samarinda Tahun 2015family members." Frontiers in public health 7: 169. Jurnal Kesehatan STIKES Muhammadiyah Samarinda 
Jurnal Kesehatan STIKES Muhammadiyah Samarinda .

Haryanti, L., Pudjiadi, A. H., Ifran, E. K. B., Thayeb, A., Amir, I. \& Hegar, B. 2016. Prevalens dan faktor risiko infeksi luka operasi pasca-bedah. Sari Pediatri, 15, 207-12.

Kemenkes. (2018). Laporan Riset Kesehatan Dasar: Cedera. Jakarta: Litbangkes RI.

Kartika, R. W. 2015. Perawatan luka kronis dengan modern dressing. Perawatan Luka Kronis Dengan Modern Dressing, 42, 546-550.

Kyeremateng-Amoah, E., Nowell, J., Lutty, A., Lees, P. S. \& Silbergeld, E. K. 2014. Laceration injuries and infections among workers in the poultry processing and pork meatpacking industries. American journal of industrial medicine, 57, 669-682.

Maryunani, A. (2015). Perawatan Luka Modern (Modern Woundcare). Jakarta: IN MEDIA

Manela, C. \& Hidayat, T. 2018. Korelasi Kadar Alkohol dengan Derajat Luka Dalam Hal Pembuatan Visum Et Repertum pada Pasien Kecelakaan Lalu Lintas Rumah Sakit M. Djamil Padang. Jurnal Kesehatan Andalas, 7, 370-374.

Morison, J. Moya, 2003. Manajemen Luka. Jakata: EGC.

Muttaqien, M. I., Hamidy, M. Y. \& Rustam, R. P. 2016. The Overview of Surgical Site Infection of Pasca Caesarean Section at Arifin Achmad General Hospital of Riau Province 1 January-31 December 2014 Period. Jom FK3.

Notoatmodjo, Soekidjo. 2010. Metodologi Penelitian Kesehatan Edisi Revisi. Jakarta : PT Rineka Cipta.

Nursalam, 2009. Konsep dan Penerapan Metodologi Penelitian Ilmu Keperawatan. Jakarta : Salemba Medika

Omoke, Njoku Isaac, 2016. Analysis of Risk Factors for Gunshot Wound Infection in a Nigerian Civilian Trauma Setting. World J Surg. Original Scientific Report. DOI 10.1007/s00268-016-3475-4 .

Praythiesh Bruce, V. M. (2019). Prevalence of complications of diabetes among patients with diabetes mellitus attending a tertiary care centre in Tamil Nadu. International Journal of Community Medicine and Public Health .

Putra, E. W. 2017. Pengaruh Berbagai Dosis Dan Konsentrasi Patikan Kebo (Euphorbia Hirta L.) Terhadap Lama Penyembuhan Luka Sayat (Vulnus Scisum) Pada Tikus Putih (Rattus Norvegicus Strain Wistar). University of Muhammadiyah Malang.

Quinn, J. V., Polevoi, S. K. \& Kohn, M. A. 2014. Traumatic lacerations: what are the risks for infection and has the 'golden period'of laceration care disappeared? Emergency Medicine Journal, 31, 96-100. doi:10.1136/emermed-2012202143. 
Rahman, T. 2017. Gambaran Kejadian Status Neuropati Perifer Pada Penyandang Diabetes Mellitus di Puskesmas Sukohardjo. Jurnal Kesehatan Unismuh Surakarta.

Rahmawanto, Y. N. 2015. Studi Deskriptif Perilaku Perawat dalam Pencegahan Infeksi Nosokomial di Ruang Rawat Inap RSUD $d r$. R Goeteng Taroenadibrata Purbalingga. Universitas Muhammadiyah Purwokerto.

Roodsari, G. S., Zahedi, F. \& Zehtabchi, S. 2015. The risk of wound infection after simple hand laceration. World journal of emergency medicine, 6, 44. DOI: 10.5847/wjem.j.1920-8642.2015.01.008.

Saryono. 2011. Metodologi Penelitian Kesehatan Penuntun Praktis Bagi Pemula. Jogjakarta: Mitra Cendikia.

Sastroasmoro, S. 2014. Dasar-Dasar Metodologi Penelitian Klinis, Edisi ke- 5. Jakarta: Sagung Seto.

Sjamsuhidajat (ed.) 2010. Buku Ajar IImu Bedah, Jakarta: EGC.

Sommeng, F. 2019. Identifikasi Bakteri Udara di Ruang Operasi dengan Bakteri pada Luka Infeksi Pasien Pasca Operasi di Rumah Sakit Ibnu Sina. UMI Medical Journal, 4, 3165.

Sulviana, A. W. 2017. Identifikasi Pseudomonas aeruginosa dan Uji Sensitivitas terhadap Antibiotik dari Sampel Pus Infeksi Luka Operasi di RSUD Dr. Moewardi. Universitas Setia Budi Surakarta.

Tandra, H. 2017. Segala Sesuatu Yang Anda Harus Ketahui Tentang Diabetes. Jakarta: PT Gramedia Pustaka Utama.

Tasijawa, J. 2018. Asuhan Keperawatan Pada Pasien Dengan Vulnus Laceratum Di Instalasi Gawat Darurat. Jurnal Kesehatan Stikes Majapahit Mojokerto .

WHO. 2016. Road traffic injuries. http://www.who.int/media center/factsheets/ fs358/en/.

Wulandari, W., Sutomo, A. H. \& Iravati, S. 2016. Angka Kuman Udara dan Lantai Ruang Rawat Inap Rumah Sakit PKU Muhammadiyah Yogyakarta. Jurnal Berkala Kesehatan, 1.

Yusuf, Saldy. 2018. Gambaran karakteristik luka dan perawatannya di ruangan poliklinik luka di RS dr. Wahidin Sudirohusodo Makassar, Jurnal luka Indonesia., 4(3): 153163 